V. AZIMIRAD, ${ }^{1}$ M. HOSSEINPOUR, ${ }^{1}$ P. SHAHABI,${ }^{2}$ M. ALIMOHAMMADI, ${ }^{1}$

M. SADIGHI, ${ }^{2}$ and H. HATAMI ${ }^{3}$

\title{
EFFECTS OF INJECTION OF CARBON NANOTUBES ON EEG AND RESULTS OF A BEHAVIORAL TEST IN RATS
}

\author{
Received January 17, 2014
}

\begin{abstract}
We examined the biocompatibility of carbon nanotubes (CNTs) injected i.p. into rats (1 mg/kg body mass) by recording EEG from the frontal and occipital cortex and performing the water maze router test before and after such injection. For EEG, the energy and average power spectral density of wavelet coefficients in the $\beta, \alpha$, and $\theta$ bands were considered the features. In the water maze router experiment, the distance, time, and speed of rats were investigated as behavioral factors. Comparison of EEG signals before and after injection showed that introduction of CNTs exerted no significant effect on electrophysiological brain indices. A comparison of behavioral factors before and after injection, however, showed that injections of CNTs increased the pacing distance and time to find the desired platform and decreased somewhat the speed in the water maze router experiment. A possible reason of this phenomenon is the possible influence of CNTs on ion fluxes in brain neurons.
\end{abstract}

\section{Keywords: carbon nanotubes, EEG, wavelet, water maze router, spatial memory.}

\section{INTRODUCTION}

Nanotechnology is an emerging field; in particular, applications of precisely engineered nanomaterials in neuroscience have been proposed [1]. Regarding the properties of these tissues, a neural interface with nanoscale components is more suitable than that with microscale devices [2]. Carbon nanotubes (CNTs) are an important class of synthetic nanomaterials; they occupy a pioneering position in nanotechnology due to their unique electrical, mechanical, thermal, and chemical characteristics.

Hence, these materials are promising in different areas of nanomedicine and, especially, of nanoneuroscience $[1,3]$. Their distinct architecture allows these objects to effectively penetrate biological barriers [4]. Having special physicochemical properties, CNTs are useful for nanomedicine

\footnotetext{
${ }^{1}$ Department of Mechanotronics, School of Engineering Emerging Technologies, University of Tabriz, Tabriz, Iran.

${ }^{2}$ Neuroscience Research Centre, Tabriz University of Medical Sciences, Tabriz, Iran.

${ }^{3}$ Department of Biology, Faculty of Science, University of Tabriz, Tabriz, Iran.

Correspondence should be addressed to V. Azimirad

(e-mail: azimirad@tabrizu.ac.ir).
}

applications; in particular, they improve the performance of drug molecules as target delivery carriers [5]. Although it has been stated that the well-dispersed CNTs have better biocompatibility in comparison with agglomerated forms $[6,7]$, the biocompatibility of these materials has not been fully demonstrated. However, the capabilities of CNTs as substrates for neuronal growth, integration with neurons, and enhancing neuronal functions are being explored [8-10]. The high electrical conductivity and excellent mechanical properties of CNTs make them a desirable material for neuroprosthetic devices [3]. Some other substantial properties are the dispersibility of CNTs in physiological solvents, large surface area, and capability of being functionalized with drugs or imaging agents [1]. The emergence of CNTs as a delivery vector for the CNS is based on their structural properties. The effectiveness of CNTs in recording neuronal electrical events has been demonstrated [11]. Another application of CNTs is intracellular and extracellular recording by using CNT probes [12]. Despite an explosion of research into applications, there is little information on the biocompatibility of CNTs.

Cohesive properties of CNTs stably occurring in the body are considered a possible factor for toxic 
influences. Another factor that may compromise the biocompatibility of CNTs is the dispersibility status and the type of surface functionalization of these materials [13, 14]. Generally, simply dispersed CNTs are more toxic than the covalently modified ones; in particular, pristine multi-walled carbon nanotubes (MWCNTs) dispersed by serum were found to be more toxic than amino-MWCNTs [15]. It has been stated that in rats CNTs cause inflammatory responses and the formation of lesions known as granulomas [16]. The toxicity investigation of MWCNTs in humans showed that CNTs may cause inflammatory and fibrotic reactions, protein exudation, and granulomas on the peritoneal side of the diaphragm [17]. However, it was reported in another study that MWCNT-COCL exerted no observable signs of damage in the spleen [18]. MWCNTs caused inhibition of neuronal calcium ion channels, which is due to the yttrium traces released from these objects [19]. Even with all previous studies on the applications of CNTs in nanomedicine, no work has been done on the effects of these nanotubes on electrophysiological events in the brain and on spatial memory.

EEG analysis has been extensively used as a tool for diagnostic monitoring of brain injuries [20] or changes in brain functions [21]. Hence, we investigated the biocompatibility of MWCNTs and their effect on brain activities through analyzing EEG signals before and after injection of MWCNTs. Some features in the time and frequency domains were selected in terms of the wavelet functions. A behavioral study (water maze router experiment) was also done before and after injection of MWCNTs to estimate changes in spatial memory.

\section{METHODS}

Carbon Nanotube Properties. Functionalized MWCNTs with carboxyl were used. The $\mathrm{COOH}$ content of these materials was 2 wt \%. They had an inner diameter of 5 to $10 \mathrm{~nm}$, an outer diameter of 10 to $20 \mathrm{~nm}$, and an individual length of $\sim 30 \mu \mathrm{m}$, according to the data provided by the manufacturer. Their purity was more than $95 \mathrm{wt} \%$. The form of MWCNTs is a black solid powder.

Animals. The experiments were carried out on six male Wistar rats with ages varying from 4 to 6 month and with body mass from 280 to $300 \mathrm{~g}$. The animals were kept under standard conditions (temperature $22 \pm 2{ }^{\circ} \mathrm{C}$ and $12 \mathrm{~h} \mathrm{light/dark}$ cycle with 08:00 AM lights on); food and water were freely available throughout the study.

Surgical Procedure. Rats were anaesthetized with ketamine and xylazine (i.p., 80 and $5 \mathrm{mg} / \mathrm{kg}$, respectively). Using a stereotaxic instrument, all animals were implanted with two cortical stainless steel electrodes in the frontal and occipital cortex for EEG recording. Electrodes were fixed in the socket by means of their pins, and the socket was fixed to the skull by dental cement.

EEG Recording and Injection. After 3-day-long recovery from surgery, the animals were settled in a Faraday cage, and EEG signals were recorded in a freely moving way using light flexible conductors. EEG signals were recorded $1 \mathrm{~h}$ before and $1 \mathrm{~h}$ after nanotube injection. One $\mathrm{mg} / \mathrm{kg}$ body mass of MWCNT corresponding to $0.3 \mathrm{mg} / \mathrm{rat}$ was i.p. injected. A sodium chloride solvent was used for MWCNT suspension preparing. The MWCNT concentration in the suspension was $0.5 \mathrm{mg} / \mathrm{ml}$. It was taken into account that CNTs have no difficulty in crossing the bloodbrain barrier [1, 22]. After control 1-h-long recording and CNT injection, EEG signals were recorded for $1 \mathrm{~h}$ 30 min after the above injection.

EEG Processing. Notch and low-pass filters were used for removing noise; the low-pass cutoff frequency was set to $32 \mathrm{~Hz}$. According to the statements of the international 10-20 system, the amplitude of EEG signals from the scalp is 0.1 to $200 \mu \mathrm{V}$, and the frequency range is 0.5 to $50 \mathrm{~Hz}$. The borders of EEG frequency components were the following: $\delta, 0.5-3.5 \mathrm{~Hz}$; $\theta, 4-7 \mathrm{~Hz} ; \alpha, 8-13 \mathrm{~Hz} ; \beta, 14-30 \mathrm{~Hz}$, and $\gamma,>31 \mathrm{~Hz}$. The energy and average power spectrum density (PSD) of the wavelet coefficients were used for feature extraction [23].

The energy of the signal $(f(t))$ is as follows:

$$
E_{f}=\int_{-\infty}^{\infty}(|f(t)|)^{2} d t
$$

Wavelet Packet Decomposition. Feature extraction methods for EEG analysis mainly include the following methods: (1) fast Fourier transform (FFT): The main disadvantage of this method was that it only uses the frequency information and does not use the time domain information. (2) Autoregressive (AR) model. From the AR spectrum, the power was calculated in multifrequency bands, and the overall power was used as an independent variable. In addition, the AR model 
coefficients or multivariate autoregressive (MVAR) model coefficients were used as features. (3) Timefrequency (TF) analysis. (4) Utilizing coefficients of wavelet transform, i.e., extracting coefficients of wavelet transform at the useful frequency bands according to transcendent information [24].

The discrete wavelet transforms decompose the signal into approximate and detailed information. The core process is filtering; $\mathrm{x}(\mathrm{n})$ was filtered by lowpass coefficients, $h(n)$, and high-pass coefficients, $\mathrm{g}(\mathrm{n})$, respectively. In each level, the down-sampled outputs of the high-pass and low-pass filters provided the detail $\mathrm{D}_{\mathrm{i}}$ and approximation $\mathrm{A}_{\mathrm{i}}$, respectively. The first approximation was further decomposed, and the process was continued until the desired result was obtained. Hence, the Daubechies mother wavelet of order 4 was used, and EEG signals were decomposed into three levels on the wavelet basis (Fig. 1).

There were three levels, 4-8, 8-16, and 16-32 Hz, which are similar to the $\theta, \alpha$, and $\beta$ ranges. The power spectral density for these coefficients was calculated as the feature, and the wavelet coefficients are shown in Fig. 2 A-C.

Spectral Estimation Method. Spectral density methods extracted information from a signal to describe the distribution of its power in the frequency domain. The PSD was defined as the Fourier transform of the autocorrelation function [25]. Here, the Welch's method was applied for estimating the PSD. It divided time-series data into overlapping segments by computing a modified periodogram of each segment. A hamming window with 64 lengths was selected, and then the PSD estimates were averaged.

Water Maze Router Experiment. The water maze router experiment was used for investigating the behavioral effect of MWCNTs on the learning ability and spatial memory of rats. The animals were put into a circular tank filled with water, and they swam to find a hidden platform below the water $\left(22\right.$ to $\left.32^{\circ} \mathrm{C}\right)$ surface. The experiment was done in a semi-dark space and a black tank with a black platform; therefore, the rats were able to minimally use their visual system for identifying and finding the platform. Three factors, the distance, time, and speed of rats to find the platform, were set as variables. The training duration was considered to be 5 days, and four trials were done every day. Finally, the values of variables in injected rats were compared with the values of corresponding variables in the control (before injection).

Statistical Analysis. Statistical analysis was performed using SPSS. The paired-sample $t$-test was done on results of the time and frequency domains. The $P$ significance values were set at 0.05 .

\section{RESULTS}

EEG Signal Analyses. Results of EEG signal analysis are presented in Table 1. It summarizes the results of average PSD of wavelet coefficients $(\beta, \alpha$, and $\theta)$ and energy before (control group) and after injection (injection group) of MWCNTs.

As shown in Table 1 and Fig. 2, the average PSD and overall energy values before injection were, in general,

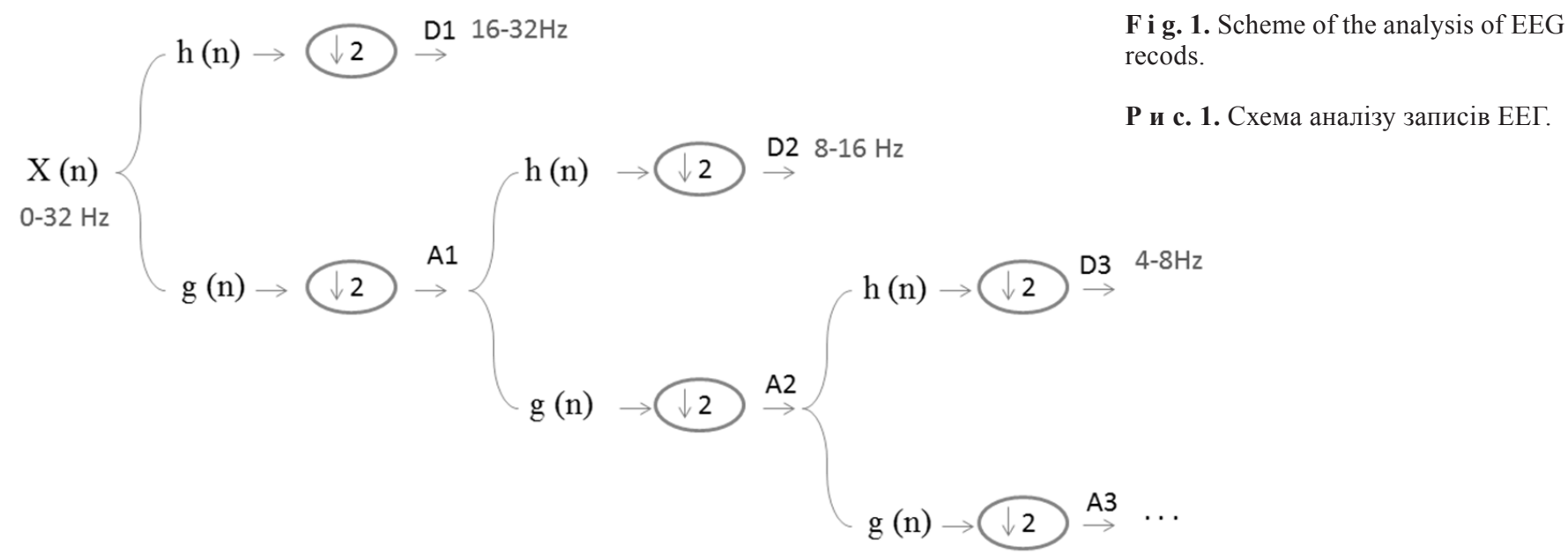


T a b l e 1. Paired-Sample Statistics for the Mean Powers of the Wavelet Coefficients and Energy Analysis of EEG

Т а б л и ц я 1. Статистика парних виборок для середніх значень потужності вейвлет-коефіціснтів та аналіз енергії для ЕЕГ

\begin{tabular}{|c|c|c|c|c|c|}
\hline Energy & $\begin{array}{l}\text { Injected } \\
\text { Control }\end{array}$ & $\begin{array}{l}0.000001 \\
0.000002\end{array}$ & $\begin{array}{l}6 \\
6\end{array}$ & $\begin{array}{l}0.4665115 \\
0.4362918\end{array}$ & 0.102 \\
\hline $\begin{array}{l}\text { Average power of the } \beta \text { band } \\
\text { (D1 coefficient) }\end{array}$ & $\begin{array}{l}\text { Injected } \\
\text { Control }\end{array}$ & $\begin{array}{l}0.00 \\
0.000619\end{array}$ & $\begin{array}{l}6 \\
6\end{array}$ & $\begin{array}{l}0.000 \\
0.0000882\end{array}$ & 0.500 \\
\hline $\begin{array}{l}\text { Average power of the } \theta \text { band } \\
\text { (D3 coefficient) }\end{array}$ & $\begin{array}{l}\text { Injected } \\
\text { Control }\end{array}$ & $\begin{array}{l}0.00 \\
0.000883\end{array}$ & $\begin{array}{l}6 \\
6\end{array}$ & $\begin{array}{l}0.000 \\
0.0001162\end{array}$ & 0.845 \\
\hline
\end{tabular}

T a b l e 2. Paired-Sample Statistics for the Time, Distance, and Speed Factors in the Water Maze Router Test

Т а б л и ц я 2. Статистика парних виборок для факторів часу, відстані та швидкості в тесті з водним лабіринтом

\begin{tabular}{|c|c|c|c|c|c|}
\hline Distance & $\begin{array}{l}\text { Injected } \\
\text { Control }\end{array}$ & $\begin{array}{l}6.3543 \mathrm{E} 2 \\
2.8265 \mathrm{E} 2\end{array}$ & $\begin{array}{l}5 \\
5\end{array}$ & $\begin{array}{c}67.7117917 \\
62.62852\end{array}$ & 0.00 \\
\hline Speed & $\begin{array}{l}\text { Injected } \\
\text { Control }\end{array}$ & $\begin{array}{l}49.0000 \\
56.6500\end{array}$ & $\begin{array}{l}5 \\
5\end{array}$ & $\begin{array}{c}5.3268189 \\
5.25179\end{array}$ & 0.031 \\
\hline
\end{tabular}

higher than their corresponding values after injection, but these differences did not reach the significance level $(P>$ $>0.05$ for all of them). Hence, injected CNTs exerted no significant effect on the brain functions, and it could be concluded that these materials are biocompatible with the CNS. On the other hand, the obtained subsequence from the behavioral study was different.

Results of the Water Maze Router Experiment. As was mentioned, the time, distance and speed factors were calculated in this experiment for two groups of rats including the control (before injection) and postinjection (after to injection). Results of the experiment are presented in Table 2. It summarizes values of the means, standard deviations, and $P$-values for the time, distance, and speed factors.

According to Table 2, the $P$-values for the distance and speed factors were lower than 0.05 . Therefore, the differences between results were significant. For the time factor, the $P$-value was 0.07 . This value was more than 0.05 , but it was considered close to significant
( $P$-values changed from 0.05 to 0.10$)$. The results for the time factor in two groups of rats including the control group and the CNT-injected group are shown in Fig. 2.

As Fig. 3A shows, the time factor in the injection group was higher than that in the control group. The results for the distance factor are shown in Fig 3B. According to this panel, the distance factor of the injection group was greater than that in the control group. The results for the speed factor in the two groups are shown in Fig. 3C. This panel demonstrates that the speed factor in the injection group was higher than the control group. As was mentioned above, according to the results of CNT injection into the rats' body, CNTs exerted no significant effect ( $P$-value $>0.05)$ on EEG signals. The results of the water maze router experiment, however, showed that CNTs had a negative effect on spatial memory, and their injection increased the time and distance factors and decreased the speed factor. 

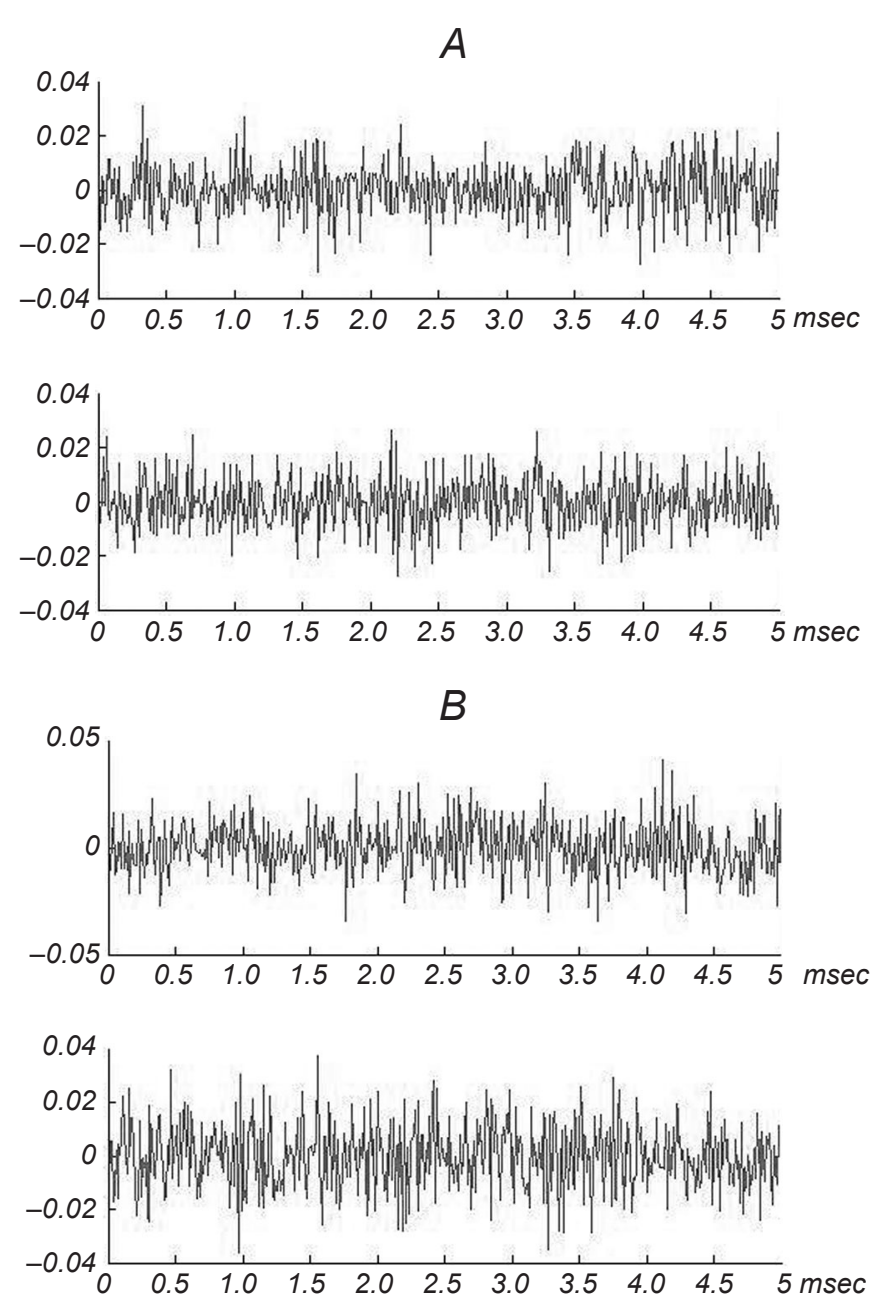

C
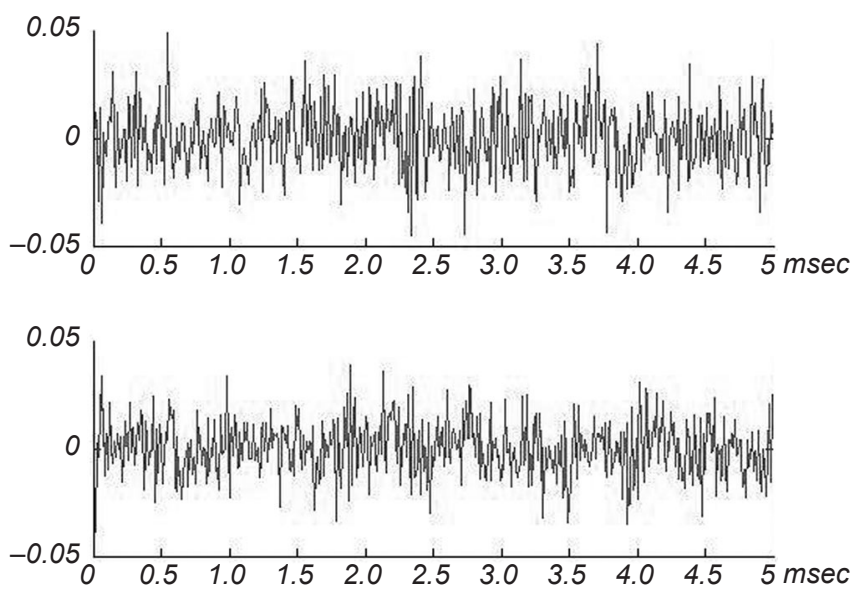

F i g. 2. Wavelet coefficients for different levels before and after injection of carbon nanotubes. A-C) Coefficients for the second (A, D1), third (B, D2), and fourth (C, D3) levels.

Р и с. 2. Вейвлет-коефіцієнти для різних рівнів перед ін'єкцією вуглецевих нанотрубок та після неї.
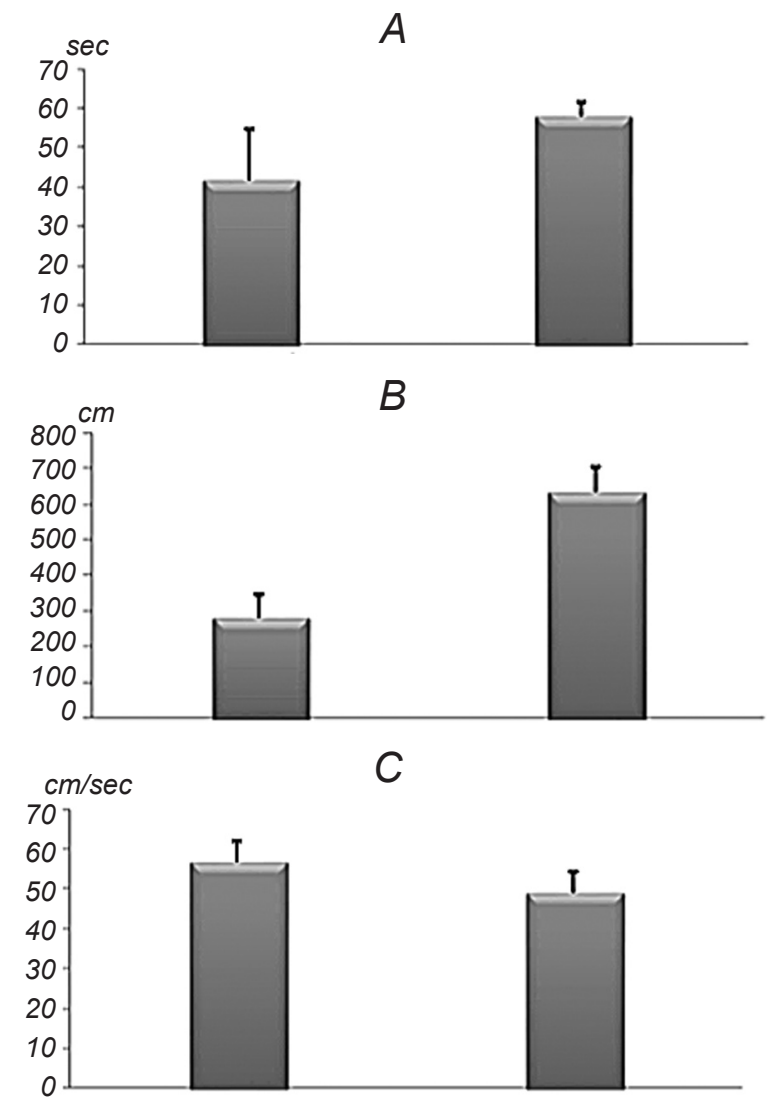

F i g. 3. Means of the time factor (A), distance factor (B), and speed factor (C) before and after CNT injection.

Р и с. 3. Середні значення факторів часу (А), шляху (В) та швидкості (C) перед ін'єкцією вуглецевих нанотрубок та після неї.

\section{DISCUSSION}

Carbon nanotubes have many applications in neuroscience, e.g., in the treatment of glioblastoma tumors [26] and neural tissue repair using neural stem cells (NSCs) [27] The CNT films are mechanically compatible with neural tissues and could be used as implants or repairing devices for neurology-related injuries [28]. CNT-mediated therapy is a valuable option for the treatment of neurodegenerative diseases, including the treatment of stroke [29]. The success of carbon nanotube applications in medicine is, however, closely dependent on their interaction with neurons, especially with respect to possible changes in the neural excitability, ion conductance, and synaptic transmission [11]. Some reports showed that the electrophysiological properties of neurons are affected after passage of electrical current through CNT-based substrates [30-32]. So far, only a few studies have 
been reported regarding the biocompatibility of CNT within the brain tissue in vivo.

The first study using CNT for the treatment of dissociated hippocampal neuronal cultures demonstrated the maintenance of neuronal viability, induction of morphological modifications in neurons, enhancement of neurites, and outgrowth and increasing suppression of growth cones. Furthermore, it was shown that MWCNTs may affect the $\mathrm{Ca}^{2+}$ dynamics in neurons (reduction of depolarization-dependent influx of $\mathrm{Ca}^{2+}$ ) [33]. Investigation of internalization and toxicity of MWCNTs and their effects on microglia cells showed that these objects are uptaken by microglia cells without manifestations of toxicity. According to these results, no changes in cell proliferation were observed in the presence of CNTs [34].

Investigations with CNTs dispersed in various surfactants showed that their cytotoxicity depends on the surfactant type. For example, sodium docecyl benzene sulfonate (SDBS) led to noticeable toxicity, while sodium cholate (SC) did not induce the latter $[35,36]$. Investigation of the effect of MWCNTs on potassium $\left(\mathrm{K}^{+}\right)$channels showed that the activity of these channels was suppressed [37]. In general, comparison of studies on the toxicity and biocompatibility of CNTs is difficult; however, it can be concluded that promising results were obtained in the studies where chemically functionalized CNTs were used [1].

According to the obtained results, CNTs showed a high biocompatibility with different cell types and no negative effects on neuronal morphology, cell viability, and basic cellular functions [38]. The in vivo investigation of results of introduction of MWCNTs revealed that they are biocompatible, and no damage at the cellular structural level has been observed until now [39]. At the same time, CNTs can block the channel pores and interrupt the ion permeability. Similarly, they caused a significant impairment of the cytoplasmic $\mathrm{Ca}^{2+}$ elevation when neurons were depolarized. This effect may be due to the CNT interference with the functioning of $\mathrm{Ca}^{2+}$ channels [40]. According to one of the previous works, injection of MWCNT can lead to a transient and self-limiting local inflammatory response [41]. The negative effect of CNTs on spatial memory was, presumably, due to a disorder of ions in the functioning of some channels and blocking of ion fluxes. The main probable factor in this phenomenon was suppression of potassium channels by MWCNTs. This may cause changes in the resting and action potentials and, therefore, affect the conduction of some signals related to spatial memory.

The study was carried out in accordance with the statements of the Council Directive regarding the protection of animals used for experimental and other scientific purposes (86/609/ EEC, 1986, Strasbourg) and respective regulations of the Ethics Committee at the Tabriz University of Medical Sciences, Tabriz, Iran.

The authors of this study, V. Azimirad, M. Hosseinpour, P. Shahabi, M. Alimohammadi, M. Sadighi, and H. Hatami, confirm that the research and publication of the results were not associated with any conflicts regarding commercial or financial relations, relations with organizations and/or individuals who may have been related to the study, and interrelations of coauthors of the article.

\section{B. Азімірад ${ }^{1}$, М. Хоссейнпур ${ }^{1}$, П. Шахабі ${ }^{2}$, M. Алімохаммаді ${ }^{1}$, M. Садігхі ${ }^{2}$, Х. Хатамі}

\section{ВПЛИВИ ІН'ЄКУВАННЯ ВУГЛЕЦЕВИХ НАНОТРУБОК НА ЕЕГ ТА РЕЗУЛЬТАТИ ПОВЕДІНКОВОГО ТЕСТУ У ЩУРІВ}

\author{
${ }^{1}$ Школа прогресивних інженерних технологій Табризь- \\ ського університету (Іран). \\ ${ }^{2}$ Центр нейронаукових досліджень Табризьського \\ університету медичних наук (Іран). \\ ${ }_{3}^{3}$ Табризьський університет (Іран).
}

Р е $з$ ю м е

Ми досліджували біосумісність вуглецевих нанотрубок (ВНТ), ін'єкованих щурам (1 мг/кг маси тіла, внутрішньоочеревинно), відводячи ЕЕГ та застосовуючи поведінковий тест із водним лабіринтом перед такою ін'єкцією та після неї. Параметрами ЕЕГ вважали енергію та усереднені щільності спектральної потужності вейвлет-коефіцієнтів для бета-, тета- та альфа-ритмів. В експерименті 3 водним лабіринтом поведінковими факторами були відстань, час та швидкість руху щурів у пошуках цільової платформи. Порівняння сигналів ЕЕГ перед ін'єкцією ВНТ та після неї показало, що введення нанотрубок істотно не впливало на електрофізіологічні показники мозку. Порівняння ж поведінкових показників перед ін'єкцією та після неї, проте, засвідчило, що введення ВНТ викликало вірогідне збільшення шляху до платформи і тривалості їі пошуків, а також деяке зменшення швидкості пересування у водному лабіринті. Можливою причиною такого феномену є вплив ВНТ на іонні токи в нейронах мозку. 


\section{REFERENCES}

1. A. Nunes, K. Al-Jamal, T. Nakajima, et al., "Application of carbon nanotubes in neurology: clinical perspectives and toxicological risks," Arch. Toxicol., 86, No. 7, 1009-1020 (2012).

2. N. A. Kotov, J. O. Winter, I. P. Clements, et al., "Nanomaterials for neural interfaces," Adv. Mater., 21, No. 40, 3970-4004 (2009).

3. A. Sucapane, G. Cellot, M. Prato, et al., "Interactions between cultured neurons and carbon nanotubes: a nanoneuroscience vignette," J. Nanoneurosci., 1, No. 1, 10 (2009).

4. A. Al Faraj, F. Fauvelle, N. Luciani, et al., "In vivo biodistribution and biological impact of injected carbon nanotubes using magnetic resonance techniques," Int. J. Nanomed., 6, 351 (2011).

5. Y. Liu and H. Wang, "Nanomedicine: Nanotechnology tackles tumours," Nat. Nanotechnol., 2, No. 1, 20-21 (2007).

6. P. Wick, P. Manser, L. K. Limbach, et al., "The degree and kind of agglomeration affect carbon nanotube cytotoxicity," Toxicol. Lett., 168, No. 2, 121-131 (2007).

7. P. M. Raja, J. Connolley, G. P. Ganesan, et al., "Impact of carbon nanotube exposure, dosage and aggregation on smooth muscle cells," Toxicol. Lett., 169, No. 1, 51 (2007).

8. M. P. Mattson, R. C. Haddon, and A. M. Rao, "Molecular functionalization of carbon nanotubes and use as substrates for neuronal growth," J. Mol. Neurosci., 14, No. 3, 175-182 (2000).

9. K. Matsumoto, C. Sato, Y. Naka, et al., "Neurite outgrowths of neurons with neurotrophin-coated carbon nanotubes," $J$. Biosci. Bioeng., 103, No. 3, 216-220 (2007).

10. V. Lovat, D. Pantarotto, L. Lagostena, et al., "Carbon nanotube substrates boost neuronal electrical signaling," Nano Lett., 5, No. 6, 1107-1110 (2005).

11. M. K. Gheith, V. A. Sinani, J. P. Wicksted, et al., "Singlewalled carbon nanotube polyelectrolyte multilayers and freestanding films as a biocompatible platform for neuroprosthetic implants," Adv. Mater., 17, No. 22, 2663-2670 (2005).

12. I. Yoon, K. Hamaguchi, I. V. Borzenets, et al., "Intracellular neural recording with pure carbon nanotube probes," PLoS One, 8, No. 6, e65715 (2013).

13. S. K. Smart, A. I. Cassady, G. Q. Lu, and D. J. Martin, "The biocompatibility of carbon nanotubes," Carbon, 44, No. 6, 1034-1047 (2006).

14. A. M. Schrand, L. Dai, J. J. Schlager, et al., "Differential biocompatibility of carbon nanotubes and nanodiamonds," Diamond Relat. Mater., 16, No. 12, 2118-2123 (2007).

15. L. Lacerda, H. Ali-Boucetta, M. A. Herrero, et al., "Tissue histology and physiology following intravenous administration of different types of functionalized multiwalled carbon nanotubes," Nanomedicine (London), 3, 149-161, doi: 10.2217/17435889.3.2.149 (April 2008).

16. C. A. Poland, R. Duffin, I. Kinloch, et al., "Carbon nanotubes introduced into the abdominal cavity of mice show asbestoslike pathogenicity in a pilot study," Nat. Nanotechnol., 3, No. 7, 423-428 (2008).

17. J. Muller, F. Huaux, N. Moreau, et al., "Respiratory toxicity of multi-wall carbon nanotubes," Toxicol. Appl. Pharmacol., 207, No. 3, 221-231 (2005).

18. X. Deng, F. Wu, Z. Liu, et al., "The splenic toxicity of water soluble multi-walled carbon nanotubes in mice," Carbon, 47, No. 6, 1421-1428 (2009).

19. L. M. Jakubek, S. Marangoudakis, J. Raingo, et al., "The inhibition of neuronal calcium ion channels by trace levels of yttrium released from carbon nanotubes," Biomaterials, $\mathbf{3 0}$, No. 31, 6351-6357 (2009).

20. P. Goel, H. Liu, D. Brown, and A. Datta, "On the use of spiking neural network for EEG classification," Int. J. Knowl.-Based Intell. Eng. Syst., 12, No. 4, 295-304 (2008).

21. K. Wu, A. Sajad, S. Omar, and W. McKay, "The effect of high frequency radio waves on human brain activity: an EEG study," Univ. Toronto J. Undergrad. Life Sci., 3, No. 1, 50-52 (2009).

22. S. Ivani, I. Karimi, and S. R. F. Tabatabaei, "Biosafety of multiwalled carbon nanotube in mice: a behavioral toxicological approach," J. Toxicol. Sci., 37, No. 6, 1191-1205 (2012).

23. M K. Kiymik, M. Akin, and A. Subasi, "Automatic recognition of alertness level by using wavelet transform and artificial neural network," J. Neurosci. Methods, 139, No. 2, 231-240 (2004).

24. W. Ting, Y. Guo-zheng, Y. Bang-hua, and S. Hong, "EEG feature extraction based on wavelet packet decomposition for brain computer interface," Measurement, 41, No. 6, 618-625 (2008).

25. P. Stoica and R. L. Moses, Introduction to Spectral Analysis, Prentice-Hall, Englewood Cliffs, New Jersey (1997).

26. D. Zhao, D. Alizadeh, L. Zhang, et al., "Carbon nanotubes enhance $\mathrm{CpG}$ uptake and potentiate antiglioma immunity," Clin. Cancer Res., 17, No. 4, 771-782 (2011).

27. E. Jan and N. A. Kotov, "Successful differentiation of mouse neural stem cells on layer-by-layer assembled single-walled carbon nanotube composite," Nano Lett., 7, No. 5, 1123-1128 (2007)

28. A. V. Liopo, M. P. Stewart, J. Hudson, et al., "Biocompatibility of native and functionalized single-walled carbon nanotubes for neuronal interface," J. Nanosci. Nanotechnol., 6, No. 5, 1365-1374 (2006).

29. H. J. Lee, J. Park, O. J. Yoon, et al., “Amine-modified singlewalled carbon nanotubes protect neurons from injury in a rat stroke model," Nat. Nanotechnol., 6, No. 2, 121-125 (2011).

30. A. Takagi, A. Hirose, T. Nishimura, et al., "Induction of mesothelioma in p53+/-mouse by intraperitoneal application of multi-wall carbon nanotube," J. Toxicol. Sci., 33, No. 1, 105-116 (2008).

31. E. B. Malarkey, K. A. Fisher, E. Bekyarova, et al., "Conductive single-walled carbon nanotube substrates modulate neuronal growth," Nano Lett., 9, No. 1, 264-268 (2008).

32. C.W. Lam, J. T. James, R. McCluskey, et al., "A review of carbon nanotube toxicity and assessment of potential occupational and environmental health risks," CRC Crit. Rev. Toxicol., 36, No. 3, 189-217 (2006).

33. Y. Ni, H. Hu, E. B. Malarkey, et al., "Chemically functionalized water soluble single-walled carbon nanotubes modulate neurite outgrowth," J. Nanosci. Nanotechnol., 5, No. 10, 1707-1712 (2005)

34. B. Kateb, M. Van Handel, L. Zhang, et al., "Internalization of MWCNTs by microglia: possible application in immunotherapy of brain tumors," NeuroImage, 37, S9-S17 (2007).

35. L. Dong, K. L. Joseph, C. M. Witkowski, and M. M. Craig, "Cytotoxicity of single-walled carbon nanotubes suspended 
in various surfactants," Nanotechnology, 19, No. 25, 255702 (2008).

36. L. Dong, C. M. Witkowski, M. M. Craig, et al., "Cytotoxicity effects of different surfactant molecules conjugated to carbon nanotubes on human astrocytoma cells," Nanoscale Res. Lett., 4, No. 12, 1517-1523 (2009).

37. H. Xu, J. Bai, J. Meng, et al., "Multi-walled carbon nanotubes suppress potassium channel activities in PC12 cells," Nanotechnology, 20, No. 28, 285102 (2009).

38. C Gaillard, G. Cellot, S. Li, et al., "Carbon nanotubes carrying cell-adhesion peptides do not interfere with neuronal functionality," Adv. Mater., 21, No. 28, 2903-2908 (2009).
39. G. Bardi, P. Tognini, G. Ciofani, et al., "Pluronic-coated carbon nanotubes do not induce degeneration of cortical neurons in vivo and in vitro," Nanomed.: Nanotechnol., Biol. Med., 5, No. 1, 96 (2009).

40. K. H. Park, M. Chhowalla, Z. Iqbal, and F. Sesti, "Singlewalled carbon nanotubes are a new class of ion channel blockers," J. Biol. Chem., 278, No. 50, 50212-50216 (2003).

41. M. VanHandel, D. Alizadeh, L. Zhang, et al., "Selective uptake of multi-walled carbon nanotubes by tumor macrophages in a murine glioma model," J. Neuroimmunol., 208, No. 1, 3-9 (2009). 